\title{
Erving Goffman and Michel Foucault - discourses analysis
}

\section{Erving Goffman i Michel Foucault - analiza dyskursów}

\author{
Andrzej Borowski \\ Katedra Socjologii i Pracy Socjalnej, Wydział Edukacyjno-Filozoficzny, \\ Akademia Pomorska w Słupsku, ul. Westerplatte 64, 76-200 Słupsk, Poland \\ E-mail address: aubor@poczta.onet.pl \\ „Pobyt w instytucjach totalnych pozostawia w osobowości jednostek niezatarte \\ piętno z którym jednostka nie zawsze potrafi /chce/ się uporać"
}

\begin{abstract}
Functioning of the man in extreme conditions posed by some social institutions was a subject of many scientific studies so far. Among them some works are taking the special place E. Goffman and M. Foucault. Every school of the power should be so checking the total structure of action influencing action/ interaction/s other in special cases and of oppositions and dodge with which this action is connected. Using to such a school analytical categories Goffman's neosymbolic of interactionism in the microsociological aspect and coming from Foucault's discourse analysis in the macrosocjological aspect a novelty especially in examinations can constitute of total institutions associated with the authority of the state.
\end{abstract}

Keywords: symbolic interactionism; discourse analysis; total institutions; power

\section{STRESZCZENIE}

Funkcjonowanie człowieka $\mathrm{w}$ skrajnych warunkach stwarzanych przez niektóre instytucje społeczne było do tej pory tematem wielu opracowań naukowych. Szczególne miejsce wśród nich zajmują niektóre prace E. Goffmana i M. Foucaulta. Każde studium władzy winno być więc badaniem totalnej struktury działań wpływającej na działania/ interakcje/ innych w szczególnych przypadkach oraz oporów i uników z którymi te działania się wiążą. Zastosowanie do takiego studium kategorii analitycznych neosymbolicznego interakcjonizmu E. Goffmana/ w aspekcie mikrosocjologicznym/ oraz pochodzących $\mathrm{z}$ analizy dyskursu M. Foucaulta/w aspekcie makrosocjologicznym/ może stanowić novum zwłaszcza w badaniach kojarzonych $\mathrm{z}$ władzą państwową instytucji totalnych.

Slowa kluczowe: symboliczny interakcjonizm, analiza dyskursu, instytucje totalne, władza. 


\section{WPROWADZENIE}

Funkcjonowanie człowieka w skrajnych warunkach stwarzanych przez niektóre instytucje społeczne było do tej pory tematem wielu opracowań naukowych. Szczególne miejsce wśród nich zajmują niektóre prace E. Goffmana i M. Foucaulta.

W ujęciu E. Goffmana człowiek /homo socialis/ nie może uciec od obecności innych ludzi i skłonności do kształtowania samego siebie odpowiednio do ich oczekiwań,podobnie jak wolny człowiek nie może uciec przed władzą w perspektywie M. Foucaulta.

Goffmanowska jednostka uwolniona spod wpływu systemu społecznego dostaje się w niewolę mikrospołecznych praw sceny, na której ciągle musi się poruszać. Już w swojej pierwszej ważnej książce E. Goffman w połowie lat pięćdziesiątych zauważył, że w teatrze życia codziennego człowiek jest nadal marionetką lecz poruszaną przez inne sznurki. To właśnie stanowi o jego oryginalności- przeniesienie uwagi ze zjawisk postrzeganych przez uczestników interakcji na zjawiska nie w pełni uświadamiane.

E. Goffman do annałów socjologii przeszedł jako czołowy teoretyk neosymbolicznego interakcjonizmu, czyli tej fazy SI, której wyłonienie zbiegło się z ukształtowaniem się na gruncie amerykańskim etnometodologii /Schutz, Garfinkel/. Należy jednak zaznaczyć, iż „otwarty kontekst świadomości” uczestników interakcji oraz pierwszeństwo społecznego procesu oddziaływania wobec systemów znaczeń pozostają $\mathrm{w}$ sprzeczności z podstawową przesłanką etnometodologii.

Mówiąc o neosymbolicznym interakcjonizmie E. Goffmana należy pamiętać o czterech perspektywach analitycznych, jakimi posługiwał się $w$ kolejnych latach swojej działalności/dramat, rytuał interakcyjny, interakcje strategiczne, układy ramowe/. Jak zauważa A. Piotrowski te perspektywy analityczne stanowiły kolejne narzędzia całościowego oglądu ładu interakcyjnego [1].

\section{GOFFMANOWSKIE ROZWAŻANIA NAD MODELAMI INTERAKCJI}

\section{1. Model dramaturgiczny}

Model dramaturgiczny jest swoistą odmianą interakcjonizmu symbolicznego, nastawioną wyłącznie na analizę zachowań komunikacyjnych, przy dużym akcencie na grę pozorów, która występuje w obrębie przelotnych interakcji w społeczeństwie.

Podstawowy wykład tej koncepcji/modelu/ E. Goffman zawarł w książce „Człowiek w teatrze życia codziennego"/"The Presentation of Self in Everyday Life", wydanej w 1956r, zaś w wersji rozszerzonej i poprawionej w 1959r. Zawarte w niej opracowanie pojęcia "prezentacji jaźni"/ self presentation/miało szczególne znaczenie dla rozwoju konceptualnych ram symbolicznego interakcjonizmu i popularyzacji samej idei jaźni jako obrazu kształtowanego w ten sposób, by służył on zamiarom działającego w konkretnej sytuacji interakcyjnej.

Wszelka aktywność uczestnika interakcji służy w modelu dramaturgicznym uzyskaniu wpływu na innych jej uczestników. Człowiek bowiem w interakcjach z innymi osobami przedstawia się im podobnie jak aktor w teatrze podczas odgrywania roli.

W tym przedstawieniu scenarzystą, reżyserem i aktorem jest on sam. Gdy w relacjach między aktorami znaczącą rolę odgrywa ich status związany $\mathrm{z}$ uczestnictwem $\mathrm{w}$ grupie lub innymi cechami osobistymi mającymi walor kulturowej ważności można mówić o interakcjach ustrukturyzowanych [2]. 
Model dramaturgiczny proponowany przez E. Goffmana koncentruje się również na tym, co dzieje się między ludźmi, którzy znajdują się twarzą w twarz/face- to- face/ z innymi po to, by realizować wspólnie jakieś zadanie, czy też osiągać osobiste cele [3].

Występy jednostki bardziej niż jej zachowanie jako całość ucieleśnia i odzwierciedla wartości oficjalne danego społeczeństwa. Występ taki jest publicznym wyrazem odnowienia i potwierdzenia wartości moralnych wspólnoty do której dana jednostka należy. Jeżeli jednostka przy tym nauczy się posługiwać właściwym zespołem znaków/symboli/, będzie mogła je wykorzystywać do upiększania swoich codziennych występów i nadawania im cenionego $\mathrm{W}$ społeczeństwie stylu. Zawartość tego zespołu symboli w dużej mierze uzależniona jest od pozycji jednostki w strukturze społecznej. Zawartość tą E. Goffman nazywa " symbolem statusu klasowego" [4].

\section{2. Model rytuału interakcyjnego}

Model rytuału interakcyjnego dotyczy wzorów interakcji, których funkcją jest zachowanie własnej i cudzej "twarzy". Przedmiotem zainteresowania socjologa nie jest jednak jednostka, jej psychiczne stany, lecz reakcje syntaktyczne, łączące działania osób biorących udział w interakcji [5]. Każde szersze zjawisko społeczne/ rodzinne, polityczne, zawodowe/ polega na powtarzalnych interakcjach. E.Goffman wyodrębnił i zanalizował wiele szczegółowych podtypów interakcji:

- niezogniskowane/unfocused/, polegające na prostej współobecności i wzajemnym dostrzeganiu się przez co najmniej dwie jednostki, które nie znały się uprzednio i nie oczekują bliższego ze sobą zapoznania. Przykładem mogą być uczestnicy ruchu ulicznego w mieście, czy klienci w kolejce w sklepie.

- zogniskowane /focused/, w których jednostki znające się wcześniej lub chcące się bliżej poznać, współpracują dla podtrzymania określonego ogniska uwagi/ np. eksponują własne stanowiska podtrzymując rozmowy towarzyskie/. Służy temu również tzw. etykieta, określająca jakich sytuacji należy unikać oraz co jest naruszeniem przypisanej roli np. uczestnika spotkania towarzyskiego [6].

Ukrywanie swego prawdziwego oblicza, względnie jego korygowanie ,aby lepiej wypaść" to podstawowe rodzaje pracy z własnym wizerunkiem. Inne z nich to tzw. zbieranie punktów, wybór i stała współpraca $\mathrm{z}$ własnym wizerunkiem. Poprzez rytuał interakcyjny jednostka ochrania i konstruuje symboliczne implikacje swoich czynów, będąc w bezpośredniej obecności obiektu mającego dla niej szczególną wartość.

Osobną kwestią jest zespół czynności rytualnych związanych z okazywaniem ludziom szacunku lub ich poniżaniem, czy też przezwyciężaniem zakłopotania. E. Goffman określa jednocześnie sposoby wyalienowania się z interakcji:

- -zaabsorbowanie się czynnikiem zewnętrznym

- -nieśmiałość

- -świadomość interakcji

- -świadomość odmienności [7].

Goffmanowski rytuał interakcyjny stanowiący konsekwencję modelu dramaturgicznego, jak zauważa M. Ziółkowski, jest grą o sumie niezerowej, przy której podejmuje się tzw. praktyki protekcyjne /ochronne/, czyli zabiegi nie dopuszczające do skompromitowania się partnera aby nie przerwać interakcji i nie naruszyć porządku społecznego [8]. Prace z tego zakresu to „Behavior in Public Places”/1963/, „Interaction Ritual"/1967/ i ,Relations Public"/1971/. 


\section{3. Model interakcji strategicznej}

Model interakcji strategicznej używany jest do opisu interakcyjnych podstępów /np. szpiegostwa, hazardu, negocjacji/. Model dramaturgiczny będący punktem wyjścia do interakcji strategicznej, zakłada, iż przedstawienie jest taką formą bezpośredniej interakcji, w której jednostka lub zespół prezentuje swą tożsamość i role aktualnym partnerom.

Regułą interakcji strategicznych jest wzajemna świadomość „drugiego dna” w wypowiedziach/ przedstawieniach/ poszczególnych osób, oraz premedytacja w reżyserowaniu własnych działań. Interakcja strategiczna sprowadza się do gry, w której obie strony chcą przekazać korzystne dla siebie, a ukryć niekorzystne informacje, jak również dotrzeć do informacji o słabych i mocnych stronach partnera. Interakcja strategiczna w przeciwieństwie do rytuału interakcyjnego jest grą o sumie zerowej, gdzie obu stronom zależy by odkryć i wykorzystać słabe strony partnera [8].

E. Goffman uważa, iż jesteśmy kimś w rodzaju szpiegów, nieustannie starających się rozszyfrować rzeczywiste oblicze bliźnich. Metoda obserwacji proponowana przez E. Goffmana nie jest jednak w tym przypadku do końca skuteczna, gdyż osoba obserwowana może wykorzystać to nastawienie, do wprowadzenia obserwatora w błąd, zwłaszcza gdy zależy jej na zachowaniu dobrego zdania na swój temat [9]. Podstawowa praca $\mathrm{z}$ tego tematu to „Strategic interaction"/1969/. Można również sięgnąć do przykładu praktycznego wykorzystania kategorii interakcji strategicznej na polskim gruncie przez socjologów z ośrodka łódzkiego [10].

\section{4. Analiza ramowa}

Analiza ramowa stanowi rodzaj metamodelu obejmującego trzy poprzednie. Ukazuje ona rolę schematów interpretacji działania w budowaniu porządku interakcyjnego. Jak podaje sam E. Goffman analiza ramowa jest" rodzajem hasła odnoszącego się do warunków organizacji ludzkiego doświadczenia" [11].

W swoich badaniach $\mathrm{z}$ lat siedemdziesiątych XX w. autor zdaje się odchodzić od symbolicznego interakcjonizmu, porzucając otwarty kontekst świadomości działającego, na rzecz badania ram/ reguł/ poznania i komunikowania, analogicznych do syntaktycznych struktur języka. Odrzuca przy tym subiektywną stronę definiowania. Autor wyróżnia dwie klasy pierwotnych ram interpretacji rzeczywistości: ramy naturalne i społeczne. Naturalne ramy interpretacji identyfikują zdarzenia ujmowane jako nie sterowane, nie ukierunkowane, nieożywione, nie kontrolowane /czysto fizyczne/. Takie nie sterowane zdarzenia są całkowicie zdeterminowane przez czynniki naturalne.

Ramy społeczne umożliwiają zrozumienie zdarzeń związanych z żywą istotą ludzką, których elementami jest wola, dążenia, czy kontrolujący wysiłek umysłowy. Działania te poddają się pewnym standardom i społecznej ocenie opartej na skuteczności, bezpieczeństwie, elegancji, dobrym smaku itp.

Każdy człowiek wykazuje tendencję do postrzegania zdarzeń w terminach pierwotnych ram, a typ ramy wyznacza sposób opisu zdarzenia, do którego się stosuje. Postrzeganie i rozumienie rzeczywistości w kategoriach analizy ramowej może napotkać jednak na szereg utrudnień/ zdumienie, sztuczki, fuszerki, działania przypadkowe, żarty/.

E. Goffman wymienia kluczowe pojęcia dla rozumienia społeczeństwa w kategoriach analizy ramowej:

- udawanie/make-believe/-figlarność, fantazje i marzenia, dramaturgia tekstów medialnych/

- współzawodnictwo/contests/ np. sportowe 
- ceremoniały/ceremonials/

- przeróbki techniczne/technical redoings/ przedstawienia, psychoterapia, eksperymenty

- zmiana tła /regroundings/ zbiórki na cele charytatywne, alpinizm, licytacja w kasynie gry [11].

We „Frame Analysis” E. Goffman przeprowadza praktyczny dowód na to, że konwencje wypowiedzi naukowej nie są bardziej nośne poznawczo niż inne konwencje. We wcześniejszych pracach to założenie było przyjęte milcząco i ono kazało autorowi ironicznie zestawiać na tym samym planie scenę z powieści i dowód naukowy z laboratorium.

Model Analizy ramowej E. Goffman zawarł przede wszystkim w pracy „Frame Analysis"/1974/, ale także „, Gender Advertisements"/1979/ i “Forms of Talk"/1981/.

Poza pracami E. Goffmana napisanymi w ramach porządku interakcyjnego w latach pięćdziesiątych i na początku lat sześćdziesiątych XX w. kilka prac naukowych poświęcił on problematyce antypsychiatrycznej. Podstawowa praca z tamtego okresu to: Asylums /1961/zawierająca $\mathrm{m}$. in. słynną charakterystykę instytucji totalnych, szczegółowy opis świata podwładnych i personelu takich instytucji oraz drogę wykolejenia moralnego na przykładzie pacjentów szpitala psychiatrycznego.

W książce Stigma /1963/- stanowiącej niepodważalny wkład autora do koncepcji dewiacji i naznaczenia społecznego, autor zdefiniował pojęcie stygmatu/jako defektu fizycznego psychicznego lub społecznego/, zaś same badania przeprowadzał z punktu widzenia osoby naznaczonej. Na szeroką skalę użył w niej autor metody biograficznej i studium przypadku, aby zanalizować środki stosowane przez ludzi naznaczonych w celu podejmowania interakcji z ludźmi normalnymi. Udowodnił przy tym, że stygmat często funkcjonuje w powiązaniu ze stereotypami na bazie nieuświadomionych oczekiwań i norm, które pełnią rolę arbitrów we wszystkich społecznych kontaktach.

„Asylums” i „Stigma” E. Goffmana analizują niezmiernie ważne problemy społeczne /trudności interakcyjne ludzi naznaczonych fizycznym lub psychicznym stygmatem, zbieżność diagnoz psychiatrycznych z potocznymi określeniami zachowań niestosownych, możliwość zachowania własnej godności w granicach instytucji totalnych/.

Postrzeganie rzeczywistości społecznej $\mathrm{z}$ perspektywy grupy pozostającej poza uznanymi strukturami społecznymi nie jest dla autora Stigmy czymś nowym. Jedenaście lat wcześniej perspektywę taką zastosował w artykule „On Cooling the Mark Out” [12].

Postrzeganie całościowej wizji porządku interakcyjnego E. Goffmana w Polsce napotyka na przeszkody w postaci znikomej ilości tłumaczeń/do chwili obecnej w całości przetłumaczono tylko jedną książkę tego autora/. Niewiele lepiej wygląda stan wyposażenia polskich bibliotek naukowych w jego prace. Do chwili obecnej nie opublikowano w Polsce kompletnej bibliografii E. Goffmana.

Twórczość E. Goffmana często spotykała się z niezrozumieniem i silną krytyką, zarówno na zachodzie jak i w Polsce /A. Gouldner [13], A. Kłoskowska [14]. Mimo wspomnianych zarzutów punkt widzenia E. Goffmana znacznie odbiega od perspektywy mikrofunkcjonalizmu czy też psychologii społecznej. Dowodem na to jest fakt, iż interakcja dla niego pozostała samoistną dziedziną badań, której różne próby uporządkowania nie można kwalifikować jako rodzaju ładu normatywnego/ prawnego, ekonomicznego [15]. Podobnie zamiarem E. Goffmana nie jest przedstawianie organizacji osobowości uczestników interkacji. Giddens pisze o E. Goffmanie: „, idiosynkratyczny obserwator życia społecznego, którego wrażliwość na subtelności świadomości praktycznej i dyskursywnej bierze się bardziej z połączenia wyrafinowanej inteligencji i swawolnego stylu niż ze skoordynowanego podejście do analizy zjawisk społecznych" [16]. 
M. Ziółkowski podkreśla iż początkowo twórczość E. Goffmana nie była traktowana zbyt poważnie, jednak stopniowo zaczęła zyskiwać uznanie w oczach swych dotychczasowych zagorzałych krytyków [17].

Zdarzają się przypadki krytyki sugerujące uprawianie przez E. Goffmana swoistej psychologii społecznej. Jako reakcję na tego typu zarzuty można przytoczyć fragment wstępu do jego książki „Interaction Ritual”: „Właściwe badanie interakcji nie wiedzie w stronę jednostki i jej psychologii, lecz raczej ku relacjom syntaktycznym, jakie zarysowują się między aktami różnych współobecnych osób" [18].

Z. Bokszański uważa to za wystarczający dowód interakcjonistycznego kierunku badań i jednocześnie widzi konieczność respektowania reguł analizy interakcjonistycznej, a nie psychologicznej [19]. Specyficznie pojmowana i prezentowana wersja symbolicznego interakcjonizmu jest obecna również w późniejszych jego pracach, a nie jest to psychologia społeczna, komentuje Z. Łapiński [20]. E. Goffman ostatecznie okazuje się być nie tylko badaczem czy komentatorem życia społecznego, lecz twórcą pewnego kodu zatrzymującego uwagę czytelnika na jego wewnętrznych właściwościach. Jego teksty to często siatka metaforycznych pojęć opatrzonych przykładami z gazet ale i z tekstów filozoficznych [21].

Lata sześćdziesiąte $\mathrm{XX}$ w. były okresem przełomu $\mathrm{w}$ wielu dziedzinach nauki. Twórczość E. Goffmana na niektóre $\mathrm{z}$ nich wywarła wielki wpływ. Przykładem jest: w ramach psychiatrii - tzw. psychiatria humanistyczna, w lingwistyce - rozwój teorii dyskursu, w antropologii - powstanie nurtu kognitywnego / poznawczego [22].

\section{TOTALNY MODEL WLADZY W UJECIU M. FOUCAULTA}

Dorobek naukowy M. Foucaulta wiąże się z pojęciem poststrukturalizmu, jako nurtu dociekań naukowych. Kierunek ten powstał w końcu lat sześćdziesiątych ubiegłego wieku we Francji. Zazwyczaj osiągnięcia tego nurtu wiązane są także z nazwiskami R. Barthesa, J. Lacana i J. Derridy.

Mimo iż podstawowe pojęcie poststrukturalizmu/ dyskurs/ było używane już przez C. Levi- Straussa jako specyficzny typ wypowiedzi mitycznych, które mogą być zawsze według określonych reguł reprodukowane. M. Foucault zrywa ze strukturalistycznym przekonaniem o uniwersalnej gramatyce języka na rzecz pluralizmu $\mathrm{w}$ tej materii. Zakłada przy tym, iż istnieją różne gramatyki dyskursu, porządkujące obraz świata przez pryzmat obowiązujących w danej kulturze zasad jego organizacji. W duchu wydarzeń 1968r. M. Foucault stwierdza, że wszystkie podmioty są podporządkowane dominującym kulturowym i ekonomicznym interesom formacji kapitalistycznej, kontynuując rozważania tym torem dochodzi również do wniosku, że nie istnieje bezstronna wiedza, gdyż każdy rodzaj wiedzy sankcjonuje podporządkowanie podmiotów instytucjom.

Poststrukturalizm stara się wykazać iluzoryczność wszystkich form legitymizacji państwa i jego instytucji. Wielość gier językowych stosowanych przez poszczególne jednostki zakłada ich heterogeniczność. Ta heterogeniczność jest podstawą demokracji, dlatego poststrukturaliści, nie wyłączając M. Foucaulta zawzięcie krytykują wszelkie formy myślenia i działania totalitarnego, często mylnie utożsamianego z myśleniem $\mathrm{w}$ kategoriach instytucji zamkniętych /totalnych/.

Metodologiczny postulat podkreślania różnic i nieredukowalnych odmienności różnych gier językowych umożliwia powstawanie nowych obszarów doświadczenia/ poznania/ . Implikacje tego postulatu wyraźnie dają się zauważyć we współczesnej antropologii, gdzie pojęcia „,swojskości” i „obcości” zastępowane są pojęciami „inności” bądź „odmienności”. 
W pierwszym okresie twórczości naukowej M. Foucault zasłynął przede wszystkim jako autor „Stów i rzeczy” [23], gdzie w imię badania praktyk dyskursywnych zrezygnował z Kartezjańskiego cogito, Kantowskiego podmiotu transcendentalnego i Husserlowskiej intencjonalności, nazywając to zjawisko - „śmiercią człowieka”. Jako wykładowca College de France w latach siedemdziesiątych XX w. doszedł do wniosku, że nie istnieją tylko relacje dyskursywne, ale i stosunki sił oraz cała skomplikowana sieć relacji władzy. Powrócił tym samym, jak zauważa T. Komendant, do swoich wczesnych fascynacji nietzscheańskich.

Eksplikacją tej zmiany poglądów stały się książki „Nadzorować i karać” oraz „Historia seksualności" [24]. Należałoby wspomnieć, iż te dwie książki stanowią zawoalowaną krytykę nurtu psychoanalitycznego i antypsychiatrycznego/ mylenie przyczyn ze skutkiem/.

Niezależnie od tej zawoalowanej krytyki M. Foucault w „Nadzorować i karać” próbuje polemizować z dyskursem marksistowskim zaś w pierwszym tomie "Historii seksualności" polemizuje z J. Lacanem, który chciał całkowicie zdyskursywizować seks.

M. Foucault odwrócił formułę, iż "Ciało jest więzieniem duszy” twierdząc, że „Dusza jest więzieniem ciała”, zaś nasze ,ja” bierze się z „ujarzmienia”. Na przełomie lat siedemdziesiątych i osiemdziesiątych XX w. po raz kolejny autor ten zmienił poglądy. W „Nadzorować i karać” oraz w Historii seksualności” ,ja” wynika z „ujarzmienia”, w dwóch kolejnych tomach „Historii seksualności”, ,ja” staje się efektem samorealizacji w wymiarze historycznym, społecznym i indywidualnym.

Ontologia M. Foucaulta pozostała jednak nietzscheańska, gdzie nie istnieje podmiot transcendentny, zaś autor koncentruje się nad pytaniem" jak zdeterminować ludzką wolę?" Szukając głównych motywów poststrukturalistycznego dyskursu M. Foucaulta należałoby zwrócić uwagę na kwestię podmiotowości i jej relacji do władzy. Pomocna może tu być analiza takich dzieł autora jak „Historia szaleństwa w dobie klasycyzmu”, „Narodziny kliniki”, „Choroba umystowa a psychologia” [25], „Nadzorować i karać”, „Historia seksualności”. „Władza to totalna struktura działań, mówi M. Foucault, ta struktura często wpływa na działania i indywidualne wybory wolnych jednostek. Ewentualne badania socjologiczne na tym polu dotyczyć mogą przypadków oporu i uników, z którymi „totalne działania władzy” się wiążą.

Charakterystyczny dla kilku prac M. Foucaulta -dyskurs kryminologiczny jest całkowicie utylitarny. Od osiemnastego wieku jeśli się kogoś karze, to nie po to by napiętnować jego czyn lecz zmienić jego stan. Kara więzienia, galery, kara śmierci nie przeobrażają, nie reformują, lecz produkują przestępstwa i przestępców. W połowie XIX w. zaczęto sobie zdawać $\mathrm{z}$ tego sprawę. Postanowiono wykorzystać przestępców do nadzorowania przestępców.

System medyczny wg Foucaulta jest dopełnieniem systemu penalnego /psychiatra współpracuje z sądem, więzieniem/. Główne pole zainteresowania M. Foucaulta to jednak systemy ludzkich wypowiedzi /dyskursy/.Dyskurs kliniczny w „Narodzinach kliniki”, dyskurs psychiatryczny w „Historii szaleństwa $w$ dobie klasycyzmu”, dyskurs penitencjarny w „Nadzorować i karać”, dyskurs seksualny w „Historii seksualności”,

Narodziny kliniki psychiatrycznej i więzienia spowodowane były potrzebą siły roboczej i tendencją do większej kontroli nad przestępcami, uznanymi przez burżuazję jako osoby zagrażające porządkowi społecznemu. Władza oraz opór lub unik wobec niej to wszechobecne cechy ludzkich interakcji. Władza jest wszędzie, jest dostępna każdemu. Można ją strategicznie rozmieszczać, chcąc osiągnąć jakieś cele, a jej zastosowania można analizować pod najróżniejszymi instrumentalnymi i normatywnymi względami.

Skuteczne sprawowanie władzy nie musi pociągać za sobą usunięcia wolności. Tam gdzie nie istnieje możliwość oporu, nie może być stosunków władzy. 
Opór, uniki i koszty z tym związane mogą powodować udoskonalanie lub modyfikację technik władzy, a to dostarcza z kolei warunków umożliwiających rozwój nowych form oporu i uników.

\section{WNIOSKI}

Każde studium władzy winno być więc badaniem totalnej struktury działań wpływającej na działania/ interakcje/ innych w szczególnych przypadkach oraz oporów i uników z którymi te działania się wiążą.

Zastosowanie do takiego studium kategorii analitycznych neosymbolicznego interakcjonizmu E. Goffmana/ w aspekcie mikrosocjologicznym/ oraz pochodzących z analizy dyskursu M. Foucaulta/w aspekcie makrosocjologicznym/ może stanowić novum zwłaszcza w badaniach kojarzonych z władzą państwową instytucji totalnych.

\section{References}

[1] A. Piotrowski, Kultura i Społeczeństwo 3 (1987) 90.

[2] W. Świątkiewicz/ red./, Społeczny świat i jego legitymizacje, Katowice, 1993, s. 9.

[3] I. Krzemiński, Co się dzieje między ludźmi, Warszawa, 1992, s. 123-132.

[4] E. Goffman, British Journal of Sociology 2(4) (1951) 294-304.

[5] E. Hałas, Społeczny kontekst znaczeń w teorii symbolicznego interakcjonizmu, Lublin, 1987, s. 104.

[6] E. Goffman, Behavior in Public Places, New York, 1963, s. 33-148.

[7] E. Goffman, Interaction ritual, New York, 1967, s. 57 \& 117-125.

[8] M. Ziółkowski, hasło- Interakcja, w: Encyklopedia Socjologii, t.1, Warszawa, 1998, s. 352.

[9] J. Tittenbrun, Interakcjonizm we wspótczesnej socjologii amerykańskiej, Poznań, 1983, s. $47-48$.

[10] M. Czyżewski, A. Piotrowski, W. A. Rostocki, Kultura i Społeczeństwo 4(1) (1990) 137-159.

[11] E. Goffman, Frame Analysis, Boston, 1988, s. 11.

[12] E. Goffman, Psychiatry 15(4) (1952) 451-463.

[13] A. Gouldner, The Coming Crisis of Western Sociology, New York, 1971, s. 379.

[14] A. Kłoskowska, Społeczna sytuacja komunikowania, w: Studia Socjologiczne, nr 4/1974.

[15] E. Goffmana, Behavior in Public Places, New York, 1963, s. 8.

[16] A. Giddens, Constitution of Society, Cambridge, 1984, s. 68.

[17] M. Ziółkowski, Znaczenie, interakcja, rozumienie, Warszawa, 1981, s. 109.

[18] E. Goffman, Interaction ritual, New York, 1967, s. 2-3 \& 117-125. 
[19] Z. Bokszański, Kultura i Społeczeństwo 31(3) (1987) 68.

[20] Z. Łapinski, Teksty 5-6 (1977) 253.

[21] M. Czyżewski, Przegląd Socjologiczny XXXIII (1981) 196.

[22] A. Piotrowski, Kultura i Społeczeństwo 3 (1987) 87.

[23] M. Foucault, Les Mots et les choses, Paris, 1966.

[24] M. Foucault, Nadzorować i karać, Warszawa, 1993/pierwsze wydanie francuskie w 1975r./, tegoż, Historia seksualności, Warszawa, 1995/pierwsze francuskie wydanie I tomu 1976, t. 2-3 w 1984r./.

[25] M. Foucault, Historia szaleństwa w dobie klasycyzmu, Warszawa, 1987/pierwsze wydanie francuskie 1961r./, tegoż, Narodziny kliniki, Warszawa, 1999/ pierwsze wydanie francuskie 1963r./, tegoż, Choroba umysłowa, a psychologia, Warszawa, 2000/ pierwsze wydanie francuskie 1954r./. 